Article

\title{
Novel Preservation Methods for Inorganic Arsenic Speciation in Model and Natural Water Samples by Stripping Voltammetric Method
}

\author{
Amra Alispahić ${ }^{1}$, Adela Krivohlavek ${ }^{2}$ and Nives Galić ${ }^{3, *}$ \\ 1 Department of Natural Sciences in Pharmacy, Faculty of Pharmacy, University of Sarajevo, \\ 71000 Sarajevo, Bosnia and Herzegovina; amra.alispahic@ffsa.unsa.ba \\ 2 Department of Environmental Protection and Health Ecology, Teaching Institute of Public Health "Andrija \\ Štampar", 10000 Zagreb, Croatia; adela.krivohlavek@stampar.hr \\ 3 Division of Analytical Chemistry, Faculty of Science, University of Zagreb, 10000 Zagreb, Croatia \\ * Correspondence: ngalic@chem.pmf.hr; Tel.: +385-1-4606-191
}

check for updates

Citation: Alispahić, A.; Krivohlavek, A.; Galić, N. Novel Preservation Methods for Inorganic Arsenic Speciation in Model and Natural Water Samples by Stripping Voltammetric Method. Appl. Sci. 2021, 11, 8811. https://doi.org/10.3390/ app11198811

Received: 20 August 2021

Accepted: 17 September 2021

Published: 22 September 2021

Publisher's Note: MDPI stays neutral with regard to jurisdictional claims in published maps and institutional affiliations.

Copyright: (c) 2021 by the authors. Licensee MDPI, Basel, Switzerland. This article is an open access article distributed under the terms and conditions of the Creative Commons Attribution (CC BY) license (https:/ / creativecommons.org/licenses/by/ $4.0 /)$.

\begin{abstract}
In this study, the preservation of As(III) in model solutions and natural groundwater samples from four locations in Croatia was conducted. Model laboratory samples were spiked with $\mathrm{As}(\mathrm{III})$ and $\mathrm{As}(\mathrm{V})$, and different complexing agents. Solutions were analysed in intervals of $24,48 \mathrm{~h}$ and during ten days after preparation. Model samples containing citric acid, sodium citrate, sodium oxalate and potassium sodium tartrate in combination with acetic acid, spiked with As(III)and As(V), showed good species preservation. As(III), in model samples, was preserved for 7 days with citric acid, and citric acid in combination with acetic acid, as well as with tartrate. As(III), in natural samples, was preserved for 6 to 12 days with potassium sodium tartrate, citric acid, and citric acid in combination with acetic acid and showed improvement, compared with unpreserved samples (oxidation in 3 days). The results showed that acetic acid alone was not successful in preserving As speciation. Good resolution of inorganic arsenic species was achieved using differential pulse anodic stripping voltammetry technique (DPASV). Since this technique is comparatively cheaper and more convenient to use than other available techniques it could become a method of choice for arsenic speciation in water.
\end{abstract}

Keywords: inorganic arsenic species; preservation; sample stability; anodic stripping voltammetry

\section{Introduction}

Arsenic participates in complex biological and chemical processes, and naturally occurs in the environment (soil, air, water, etc.) in different oxidation states and species that have different chemical behaviours and toxicities [1,2]. Inorganic species are more toxic than organic arsenic compounds like monomethyl- and dimethyl arsenic, which are predominant in living organisms [3]. The reduced inorganic species, trivalent arsenic $\mathrm{As}(\mathrm{III})$, is approximately 60 times more toxic than oxidized, pentavalent arsenic $\mathrm{As}(\mathrm{V})[4,5]$. Therefore, arsenic speciation analysis of environmental samples is necessary.

According to the World Health Organization (WHO) report, the maximum permissible concentration of arsenic in drinking water is $10 \mu \mathrm{g} \mathrm{L}^{-1}$ [6]. In groundwater, arsenic is predominantly present as $\mathrm{As}(\mathrm{III})$ and $\mathrm{As}(\mathrm{V})$ [7]. The stability of sample plays a significant role in species content determination. Between sampling and laboratory analyses, changes in the species composition should be avoided. Otherwise, a suitable procedure for the preservation of the species should be implemented.

It should be noted that there are inconsistencies in published data on the preservation procedures for stabilizing aqueous inorganic $\mathrm{As}(\mathrm{III} / \mathrm{V})$ redox species. Oxidation of $\mathrm{As}(\mathrm{III})$ is the most commonly observed change, although reduction of $\mathrm{As}(\mathrm{V})$ has also been reported [8]. The stability of As(III) in groundwater was reported to be 2 days [8], 3 weeks [9], and even 3 months [10]. The addition of ascorbic acid, $\mathrm{HCl}, \mathrm{HNO}_{3}$ and $\mathrm{H}_{2} \mathrm{SO}_{4}$ 
as preservative agents has been described previously in the literature. It has been published that ascorbic acid oxidizes $\mathrm{As}(\mathrm{III})$ in natural water samples as well as $\mathrm{HNO}_{3}$ [8]. $\mathrm{HCl}$ is not suitable when inductively coupled plasma mass spectrometry (ICP-MS) is used for detection, due to the ${ }^{40} \mathrm{Ar}^{35} \mathrm{Cl}^{+}$molecular interference on monoisotopic ${ }^{75} \mathrm{As}^{+}[11,12] . \mathrm{H}_{2} \mathrm{SO}_{4}$ showed good preservation activity in model water samples but it is a poor preservative in natural water samples [13].

Groundwater often has high iron concentration [14]. Oxygen alone is not able to oxidize As(III), so dissolved ferric ions, other redox active ions or surface active substances are necessary for this reaction [15]. Complexation of iron in combination with a moderate acidification for avoiding the precipitation might stabilize arsenic species in water samples until laboratory analysis [16]. Disodium ethylenediaminetetraacetic acid (EDTA) is usually used as preserving agent when determining arsenic speciation by chromatographic techniques (ion chromatography (IC)) or high-performance liquid chromatography (HPLC)) with $\mathrm{ICP}-\mathrm{MS}$ detection. EDTA binds the $\mathrm{Fe}, \mathrm{Mn}$ and $\mathrm{Al}$ cations, preventing their interaction with arsenic and the subsequent precipitation of complexes formed [16].

Hydroxy acids also coordinate metal ions well and are used in the farming and metal industries as complexing agents for micronutrients in soil fertilizers and for cleaning metal surfaces, such as those of aluminium, copper, iron and their alloys. For example, oxalate, the conjugate base of oxalic acid, is an excellent ligand for metal ions [17-19]. The efficiency of preservatives for $\mathrm{As}(\mathrm{III}) / \mathrm{As}(\mathrm{V})$ stabilization depends on the sample matrix and microbial activity. There is no universal preservative that is effective for all water samples, so individual sample matrices need to be tested for species stability before a particular preservative can be employed. To produce representative data on species distribution, knowledge of the various processes that influence the interconversion of arsenic species is necessary. Filtration, refrigeration at $4{ }^{\circ} \mathrm{C}$ and storage in dark conditions are recommended in arsenic-species stabilization, as well as preparation of standards in distilled-deionised water [20].

The preservation of arsenic species also depends on the analytical technique to be used. $\mathrm{HCl}$ is better suited if hydride generation atomic spectrometric techniques are used, while for ion chromatography/high-performance liquid chromatography with inductively coupled plasma mass spectrometry (IC/HPLC-ICP-MS), EDTA-acetic acid preservation is preferred [21].

For arsenic speciation in water, HPLC-ICP-MS [22], capillary electrophoresis coupled to UV [23] or MS [24] and surface-enhanced Raman spectroscopy [25,26] are routinely used. Electrochemical methods were also found to be convenient and reliable for arsenic detection [27-31]. Total inorganic arsenic content analysis is normally based on converting all arsenic species into the trivalent arsenic form, which is then determined by electrochemical techniques, while As(V) is electro inactive [7]. The anodic stripping voltammetry (ASV) is very sensitive and suitable for analysis of inorganic arsenic ions in water at ppb levels [31].

Differential pulse anodic stripping voltammetry (DPASV) speciation of trace-level inorganic arsenic compounds, using the scTRACE Gold electrode, offers a simple, highly affordable alternative to the spectroscopic determination of arsenic. The electrode allows straightforward and reliable monitoring of the WHO-permitted value for arsenic in drinking water of $10 \mu \mathrm{g} \mathrm{L}^{-1}$. Using an scTRACE Gold is very easy, because its sensor combines all three of the electrodes needed for the measurement. The gold microwire working electrode eliminates the need for the laborious preparation and conditioning of the electrode, and the screen-printed $\mathrm{Ag} / \mathrm{AgCl}$ reference electrode is completely maintenance-free. As with any electrode, the performance of the scTRACE Gold deteriorates as more determinations are performed. Another advantage of voltammetric determination with the scTRACE Gold is the ability to differentiate between As(III) and As(tot) simply through the choice of measuring parameters, so this technique was used for this work [30,31].

The aim of this research was to investigate the influence of different preservatives on the stability of inorganic arsenic species in model and natural groundwater samples by DPASV. The problem to be solved was the stabilisation of the state of arsenic species 
distribution from the moment of sampling until analysis. Here, the effects on the stability of $\mathrm{As}(\mathrm{III}) / \mathrm{As}(\mathrm{V})$ ratio of four different complexing agents. including citric acid (CA), sodium citrate $(\mathrm{NaC})$, potassium oxalate $(\mathrm{OX}, \mathrm{OKS})$ and potassium sodium tartrate (TAR), were investigated, as well as the combination of these agents with acetic acid (HAc).

\section{Materials and Methods}

\subsection{Reagents}

The standards were prepared from As(III) standard solution $\left(\gamma(\mathrm{As}(\mathrm{III}))=1000 \mathrm{mg} \mathrm{L}^{-1}\right)$ purchased from CPAchem Ltd., Stara Zagora, Bulgaria and As(V) standard solution $\left(\gamma(\mathrm{As}(\mathrm{V}))=1000 \mathrm{mg} \mathrm{L}^{-1}\right)$ purchased from Inorganic Ventures, Christiansburg, VA, USA. Sulfamic acid, $\mathrm{H}_{3} \mathrm{NO}_{3} \mathrm{~S}$ 99.3\% (Sigma-Aldrich Company Ltd., Dorset, UK), citric acid, $\mathrm{C}_{6} \mathrm{H}_{8} \mathrm{O}_{7}$ (Fisher Scientific UK Ltd., Bishop Meadow Road, Loughborough, UK), potassium chloride, $\mathrm{KCl}$ 99.5\% and acetic acid, $\mathrm{CH}_{3} \mathrm{COOH}$ 99.8\% (Lach-Ner s.r.o., Neratovice, Czech Republic), potassium permanganate, $\mathrm{KMnO}_{4}$ (Sigma-Aldrich Company Ltd., Dorset, UK), methanol $\mathrm{CH}_{3} \mathrm{OH}$ 99.9\%, HPLC grade (PanReac, AppliChem GmbH, Darmstadt, Germany), sodium citrate, $\mathrm{C}_{6} \mathrm{H}_{5} \mathrm{O}_{7} \mathrm{Na}_{3} \times 2 \mathrm{H}_{2} \mathrm{O}$ and potassium-sodium tartrate tetrahydrate, $\mathrm{KNaC}_{4} \mathrm{H}_{4} \mathrm{O}_{6} \cdot 4 \mathrm{H}_{2} \mathrm{O}$ (Merck, Darmstadt, Germany), sodium oxalate, $\mathrm{Na}_{2} \mathrm{C}_{2} \mathrm{O}_{4}$ (Kemika, Zagreb, Croatia) were used. All tests were performed in the laboratory of the Division for Environmental and Occupational Health, Teaching Institute of Public Health "Andrija Štampar", Zagreb, Croatia.

\subsection{Preparation of Standard Solutions}

Standard mix solution of As(III) and As(V) $\gamma=10 \mu \mathrm{g} \mathrm{L}^{-1}$ was prepared by diluting the stock solutions of $\mathrm{As}(\mathrm{III})$ and $\mathrm{As}(\mathrm{V})\left(\gamma=1000 \mathrm{mg} \mathrm{L}^{-1}\right)$ in double-distilled water. Fresh standard solutions of lower concentrations, as standard addition in anodic stripping voltammetry technique, were made from the stock solutions every day.

\subsection{Model Sample Solutions Preparation}

Model subsamples were prepared from mix solution of As(III) and As(V). Nine subsamples were prepared by the addition of different substances as stabilisation agents in final concentration of $2 \mathrm{mmol} \mathrm{L}^{-1}$ and one without any substance added. The added stabilising agents were citric acid, sodium citrate, potassium-sodium tartrate, sodium oxalate and acetic acid 5\%, as well as these substances in combination with acetic acid. The stabilisation agents were added immediately after preparation of the $\mathrm{As}(\mathrm{III}) / \mathrm{As}(\mathrm{V}) \mathrm{mix}$ solution. The prepared subsamples were analysed within $2 \mathrm{~h}$ from preparation. These results were defined as the initial state. The same samples were measured after $24 \mathrm{~h}$, and then after $48 \mathrm{~h}$, and then during one week and ten days. All samples were stored at room temperature and in the dark until analysis. All chemicals used in this investigation were of analytical grade (99\%). All solutions were prepared using double-distilled water. All measurements were done in duplicate, and the results presented are the mean values.

\subsection{Ground Water Sample Collection and Sample Treatment}

Well water samples from four locations (two near Zagreb, two from Osijek) were used as a natural water sample for the conducted experiments. Ground, drinking and mineral water can usually be analysed directly without further processing of the samples. During sampling, well water was collected in 2000-mL polyethylene bottles. After that, 200-mL subsamples were prepared in the same way as the model laboratory samples, by adding the stabilising agents at a final concentration of $2 \mathrm{mmol} \mathrm{L}^{-1}$, and the bottles were shaken vigorously. Subsamples were prepared in polyethylene bottles. From all four locations, one subsample was left without any addition. Samples were transported to the laboratory and first analyses were done within $24 \mathrm{~h}$ of sample collection. All samples were measured after $24 \mathrm{~h}$, which is a typical period for field samples, and then after $48 \mathrm{~h}$, at one week and at ten days. All samples were stored at room temperature and in the dark until analysis. All measurements were done in duplicate, and the results presented are the mean values. 


\subsection{Preparation of Supporting Electrolyte Solution}

Sulfamic acid $(9.71 \mathrm{~g})$, citric acid $(10.51 \mathrm{~g})$ and $\mathrm{KCl}(3.35 \mathrm{~g})$ were dissolved in ultrapure water using an ultrasonic bath. The solution was made up to $100 \mathrm{~mL}$ with ultrapure water.

\subsection{Instrumentation}

Anodic stripping voltammetry was performed by using a Metrohm 797 VA Computrace Voltammograph (Metrohm, Switzerland) equipped with a voltammetric cell, a multi-mode scTRACE Gold electrode and a motor-driven PTFE stirring rod. The instrument was controlled by a computer using the VA Computrace software version 1.3.2 (Metrohm, Switzerland). The method used was previously published and recommended by the manufacturer for arsenic-species determination. An ScTRACE Gold electrode with gold wire as a working electrode, a glassy carbon auxiliary electrode and $\mathrm{Ag} / \mathrm{AgCl} /$ saturated $\mathrm{KCl}$ double-junction reference electrode were used. For determination of the total arsenic content, $\mathrm{As}(\mathrm{III})$ and $\mathrm{As}(\mathrm{V})$ were reduced at the surface of the gold electrode at $-1200 \mathrm{mV}$ to As(0), which was preconcentrated on the electrode surface. During the subsequent voltammetric determination the preconcentrated $\mathrm{As}(0)$ was again oxidized to $\mathrm{As}(\mathrm{III})$. Before the voltammetric determination of arsenic, activation of the scTRACE Gold electrode was performed. The $\mathrm{pH}$ of natural water samples was determined with a pHmeter, MPC 227, Mettler Toledo, OH, USA.

\subsection{Activation of the scTRACE Gold Electrode}

The activation of a new electrode must be carried out prior to its first use. A cleaning solution, containing $0.373 \mathrm{~g} \mathrm{KCl}$ and $2.78 \mathrm{~mL} \mathrm{w}\left(\mathrm{H}_{2} \mathrm{SO}_{4}\right)=96 \%$ in ultrapure water, was placed into the measuring vessel. Activation was carried out using the parameters given by the manufacturer. The measuring mode was direct current, with start potential of $-1.5 \mathrm{~V}$ and end potential of $1 \mathrm{~V}$. The cleaning potential was $0.1 \mathrm{~V}$ and cleaning time $5 \mathrm{~s}$, with a stirring speed of $2400 \mathrm{~min}^{-1}$.

\subsection{Determination of As(III)}

The sample $(10 \mathrm{~mL})$ was placed into the measuring vessel and $2 \mathrm{~mL}$ of the supporting electrolyte was added. The concentration of As(III) was quantified by two standard additions of As(III) standard solution. As(III) determination was carried out using anodic stripping voltammetry. The determination was carried out with the following parameters: a conditioning step, consisting of five cyclic scans from -0.2 to $+1.0 \mathrm{~V}$ at a scan rate of $100 \mathrm{mVs}^{-1}$ in the supporting electrolyte to remove any deposited As or other elements. The deposition potential of $-0.6 \mathrm{~V}$ was held for $60 \mathrm{~s}$ to reduce $\mathrm{As}(\mathrm{III})$ to $\mathrm{As}(0)$, then followed by a waiting period of $10 \mathrm{~s}$. During the stripping step, the deposited $\mathrm{As}(0)$ is reoxidized to As(III) giving the analytical signal. The anodic stripping was performed by scanning from $-0.3 \mathrm{~V}$ to $+0.4 \mathrm{~V}$ with a potential step of $0.01 \mathrm{~V}$ and frequency $100 \mathrm{~Hz}$. For the determination of $\mathrm{As}(\mathrm{III})$, the deposition potential should not be more negative than $-0.6 \mathrm{~V}$, otherwise the $\operatorname{As}(\mathrm{V})$ would also be partly reduced and deposited. The arsenite peak is located at approximately $+0.0 \mathrm{~V}$. No signal was detectable in the blank solution (containing only supporting electrolyte and deionised water instead of sample). In these analytical measurement procedures, two standard additions were performed and the corresponding currents $(\mu \mathrm{A})$ were measured after subtraction of the background current. The signal current was then plotted against concentration. The concentration of arsenic was calculated from the slope of the regression curve, drawn through the points. Two measurements were done per analysis, from which the average peak current was computed.

\subsection{Determination of As(total)}

A Sample $(10 \mathrm{~mL})$ was pipetted into the measuring vessel and $2 \mathrm{~mL}$ electrolyte was added. Then $0.1 \mathrm{~mL} \mathrm{KMnO}_{4}$ solution needed to be added if the sample contained As(III) and $\mathrm{As}(\mathrm{V})$. If the sample only contained $\mathrm{As}(\mathrm{V})$, the addition of $\mathrm{KMnO}_{4}$ solution was not required. With this method, the sum of $\mathrm{As}(\mathrm{III})$ and $\mathrm{As}(\mathrm{V})$ in the sample was determined. 
During the determination and under the stated conditions, $\mathrm{As}(\mathrm{V})$ is reduced in-situ by nascent hydrogen to As(III). Together with the As(III) present in the sample it is further reduced electrochemically to $\operatorname{As}(0)$ and deposited on the gold working electrode in the same step. During the subsequent stripping step the deposited $\mathrm{As}(0)$ is reoxidized to As(III) giving the analytical signal. The concentration of As(total) was quantified by two additions of $\mathrm{As}(\mathrm{V})$ standard solution. The conditions for $\mathrm{As}(\mathrm{V})$ determination were employed by setting the operating parameters as follows: an initial purging time of $300 \mathrm{~s}$, a stirring rate $2000 \mathrm{rpm}$, a start of potential $-0.30 \mathrm{~V}$, a deposition time of $60 \mathrm{~s}$, an equilibration time of $5 \mathrm{~s}$, an end potential of $0.40 \mathrm{~V}$, a voltage step of $0.01 \mathrm{~V}$, an amplitude of $0.02 \mathrm{~V}$, a frequency of $100 \mathrm{~Hz}$ and a sweep rate of $700 \mathrm{mV}$. After the potential scanning, a voltammogram was recorded and peak current $(\mu \mathrm{A})$ at the peak potential of $0.0 \mathrm{~V}$ was measured. $\mathrm{As}(\mathrm{V})$ concentrations were evaluated by subtracting the As(III) concentrations from As(tot). Two measurements were done per analysis, from which the average peak current was computed.

\section{Results and Discussion}

\subsection{Model Solution Experiments-As(III/V) Stability in Preserved and Unpreserved Model Solutions}

Differential pulse anodic stripping voltammetry (DPASV) was used to evaluate the sensitivity for arsenic analysis and speciation of groundwater. The DPASV voltammograms of As(III) for a $10 \mu \mathrm{g} \mathrm{L}{ }^{-1}$ standard solution with the addition of $\mathrm{NaC}$ with scTRACE Gold electrode are shown in Figure 1.
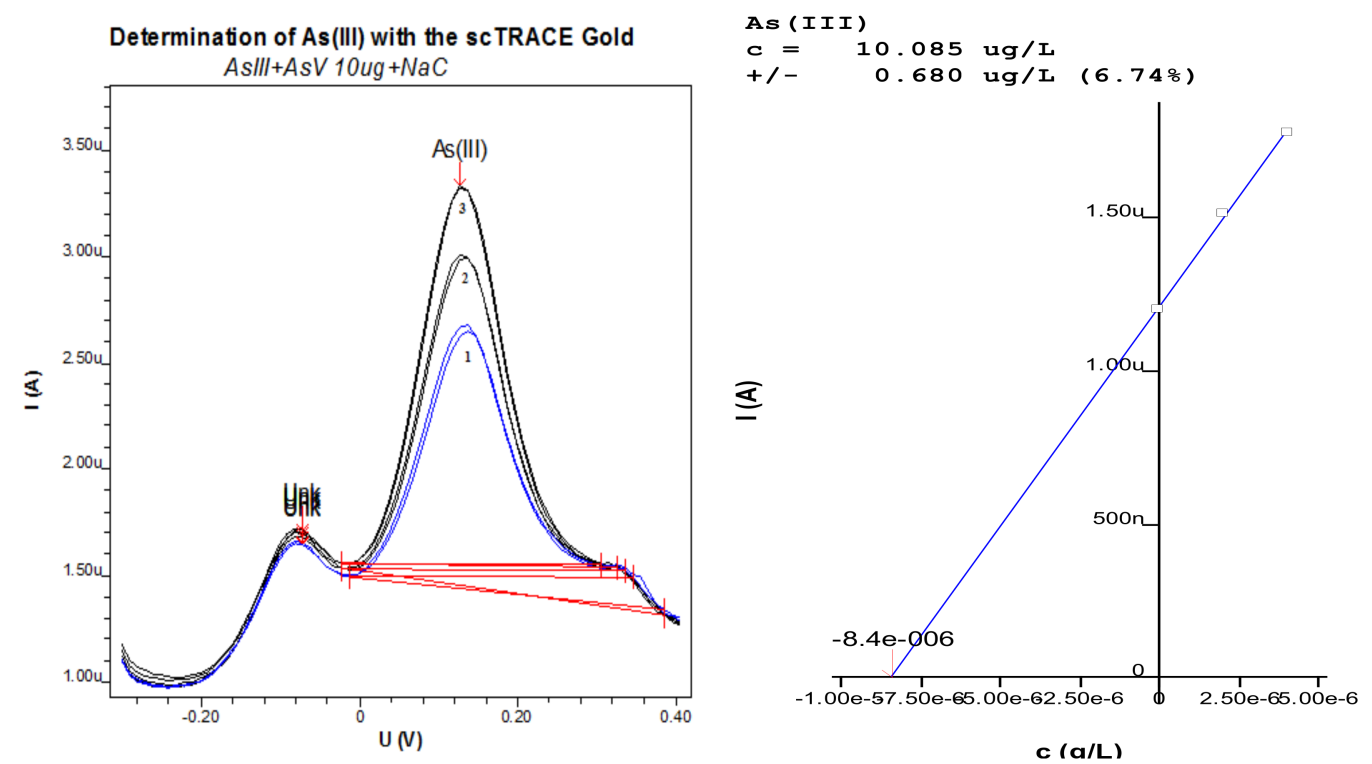

Figure 1. Resulting voltammogram obtained for the determination of As(III) in $\mathrm{As}(\mathrm{III}) / \mathrm{As}(\mathrm{V})$ $10 \mu \mathrm{g} \mathrm{L}^{-1}$ model sample with the addition of $\mathrm{NaC}$ solution in a final concentration $\mathrm{c}=2 \times 10^{-3} \mathrm{~mol} \mathrm{~L}^{-1}$ (1); (2) after the first addition $30 \mu \mathrm{L}$ of $1 \times 10^{-3} \mathrm{~mol} \mathrm{~L}^{-1} \mathrm{As}(\mathrm{III})$ standard solution; (3) after the second addition of the same standard solution and corresponding analytical curve. Voltammograms obtained for As(tot) determination in As(III)/ As(V) $10 \mu \mathrm{g} \mathrm{L}^{-1}$ model sample with $\mathrm{OX}$ solution as a preservative $\left(\mathrm{c}(\mathrm{OX})=2 \times 10^{-3} \mathrm{~mol} \mathrm{~L}^{-1}\right)$ and corresponding analytical curve are shown in Figure 2. Measurements were performed one hour after the preparation of the samples. 

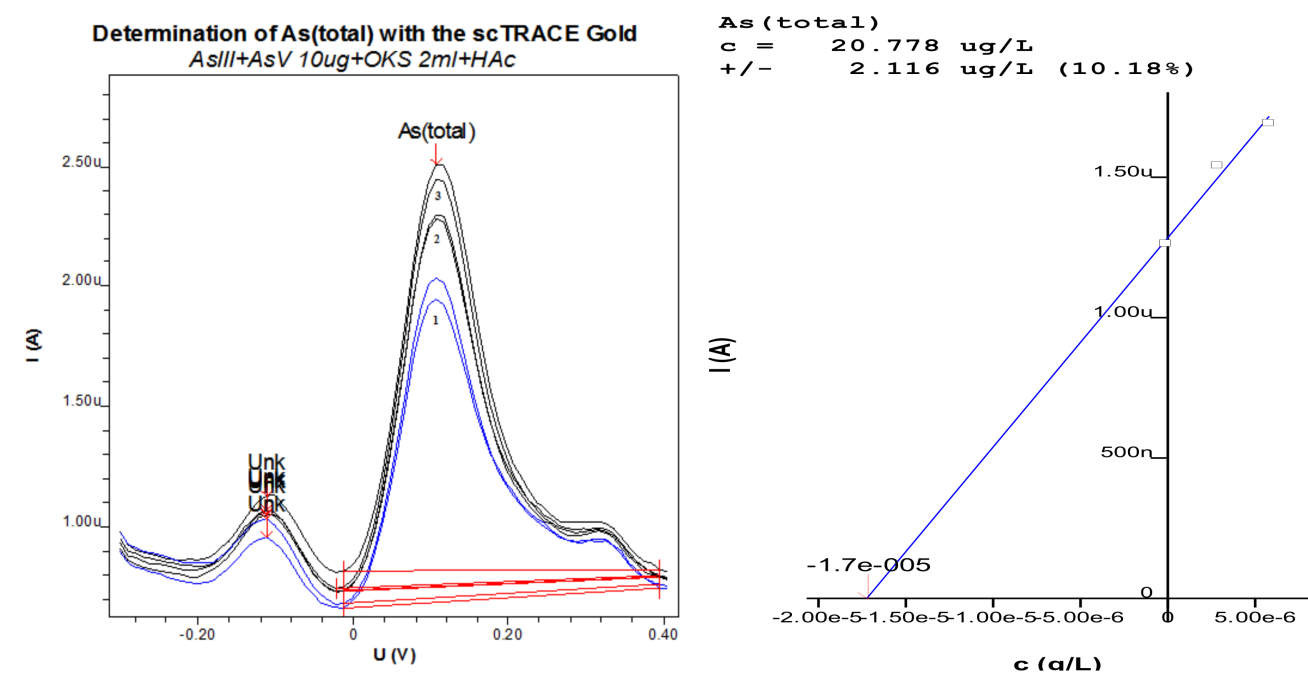

Figure 2. Voltammograms for As(tot) in $\mathrm{As}(\mathrm{III}) / \mathrm{As}(\mathrm{V})$ model solution $\left(\gamma=10 \mu \mathrm{g} \mathrm{L}^{-1}\right)$ with addition of OX $\left(\mathrm{c}(\mathrm{OX})=2 \times 10^{-3} \mathrm{~mol} \mathrm{~L}^{-1}\right.$ and HAc solution (1); (2) after first addition of $50 \mu \mathrm{L} \mathrm{As}(\mathrm{V})$ standard solution $\left(\mathrm{c}=1 \times 10^{-3} \mathrm{~mol} \mathrm{~L}^{-1}\right)$; (3) after second addition of the same standard solution and corresponding analytical curve.

The voltammograms were recorded for all model samples at 10 days and results are presented in Table 1.

The redox species distribution remained unchanged for 3 days in double-distilled water without preservatives (Figure 3a). However, with the addition of preservatives, the stability time was increased to 5 days and longer. For example, the addition of CA/HAc mixture (Figure 3b) prolonged the solution's stability up to 6 days. After that period, the reduction of $\mathrm{As}(\mathrm{V})$ occurs and the increase of $\mathrm{As}(\mathrm{III})$ concentration was the same as in unpreserved sample.

The same trend was observed for samples with higher arsenic concentrations $\left(\gamma(\operatorname{As}(\mathrm{III}))=\gamma(\operatorname{As}(\mathrm{V}))=50 \mu \mathrm{g} \mathrm{L}^{-1}\right)$. The sample preserved with $\mathrm{NaC} / \mathrm{HAc}$ was stable for 8 days (Table 1) and, after that period, the oxidation of As(III) was noticed. Since this model solution was made from a combination of standard solutions of $\mathrm{As}(\mathrm{III})$ and $\mathrm{As}(\mathrm{V})$ with the addition of sodium citrate and acetic acid, oxidation can be stimulated either by the added citrate or by $\mathrm{As}(\mathrm{V})$ itself. According to the electrode potentials, arsenate is an oxidant in an acidic environment $\left(\mathrm{E}^{\circ}=0.560 \mathrm{~V}\right)$. Since the model solutions were slightly acidic, with a $\mathrm{pH}$ between 5 and 6.5 , we believe that $\mathrm{As}(\mathrm{V})$ acted as a weak oxidant. Sodium citrate acted as a weak reductant $\left(\mathrm{E}^{\circ}=-0.180 \mathrm{~V}\right)$. The sample with TAR/HAc was stable for 7 days and then the reduction of $\mathrm{As}(\mathrm{V})$ occurs (Table 1$)$.

The obtained results are in accordance with previously reported slow reduction of $\mathrm{As}(\mathrm{V})$ in distilled and deionised water by Hall et al. [8], who found the nearly complete reduction of $\mathrm{As}(\mathrm{V})$ at concentrations $\gamma=0.5$ and $5 \mathrm{mg} \mathrm{L}^{-1}$ within 2 days. Similar results were also observed in deionised water by Bednar et al. [11]. However, our results are not consistent with those of other authors, who found less than 3\% change in the As redox distribution after 78 days in a sample adjusted to $\mathrm{pH} 2$ with $\mathrm{HCl}[32,33]$. It should be noted that samples with no addition of HAc were not stable for longer than 3 days, and in these samples, algae formation occurred after few days. Therefore, it can be concluded that acidification is necessary step in sample preparation. 
Table 1. Influence of preservation methods on stability of arsenic speciation in $\mathrm{As}(\mathrm{III}) / \mathrm{As}(\mathrm{V})$ $10 \mu \mathrm{g} \mathrm{L}^{-1}$ model samples.

\begin{tabular}{|c|c|c|c|c|c|c|c|}
\hline \multirow[t]{2}{*}{ Sample } & \multicolumn{7}{|c|}{ Time after Sampling } \\
\hline & $3 \mathrm{~h}$ & $24 \mathrm{~h}$ & $48 \mathrm{~h}$ & 3 days & 7 days & 9 days & 10 days \\
\hline \multicolumn{8}{|c|}{ 1: Unpreserved } \\
\hline As(III) & 10.01 & 10.91 & 9.85 & 11.00 & 14.30 & $\mathrm{a}$ & 17.01 \\
\hline $\mathrm{As}(\mathrm{V})$ & 9.48 & 10.52 & 10.13 & 9.66 & 6.20 & a & 3.00 \\
\hline \multicolumn{8}{|c|}{ 2: $\mathrm{CA}, \mathrm{c}=2 \times 10^{-3} \mathrm{~mol} \mathrm{~L}^{-1}$} \\
\hline As(III) & 9.84 & 9.11 & $\mathrm{a}$ & 9.14 & 10.14 & 18.10 & 16.50 \\
\hline $\mathrm{As}(\mathrm{V})$ & 10.24 & 12.89 & a & 10.86 & 10.00 & 1.90 & 3.50 \\
\hline \multicolumn{8}{|c|}{ 3: $\mathrm{CA}, \mathrm{c}=2 \times 10^{-3} \mathrm{~mol} \mathrm{~L}^{-1}+\mathrm{HAc}$} \\
\hline As(III) & 8.74 & 9.81 & 11.70 & 9.31 & 9.87 & $\mathrm{a}$ & 13.30 \\
\hline $\mathrm{As}(\mathrm{V})$ & 11.42 & 10.19 & 8.13 & 10.89 & 9.50 & a & 6.70 \\
\hline \multicolumn{8}{|c|}{ 4: $\mathrm{NaC}, \mathrm{c}=2 \times 10^{-3} \mathrm{~mol} \mathrm{~L}^{-1}$} \\
\hline As(III) & 10.09 & 9.46 & 9.83 & 3.4 & 3.79 & a & a \\
\hline $\mathrm{As}(\mathrm{V})$ & 8.92 & 10.55 & 9.67 & 20.40 & 23.41 & a & a \\
\hline \multicolumn{8}{|c|}{ 5: $\mathrm{NaC}, \mathrm{c}=2 \times 10^{-3} \mathrm{~mol} \mathrm{~L}^{-1}+\mathrm{HAc}$} \\
\hline $\mathrm{As}(\mathrm{III})$ & 9.75 & 9.46 & 8.40 & 9.71 & 9.57 & 9.90 & 5.50 \\
\hline $\mathrm{As}(\mathrm{V})$ & 9.95 & 11.57 & 12.20 & 10.29 & 10.22 & 10.10 & 14.52 \\
\hline \multicolumn{8}{|c|}{ 6: TAR, $\mathrm{c}=2 \times 10^{-3} \mathrm{~mol} \mathrm{~L}^{-1}$} \\
\hline As(III) & 10.48 & 10.56 & $\mathrm{a}$ & 14.80 & 13.77 & $\mathrm{a}$ & 20.01 \\
\hline $\mathrm{As}(\mathrm{V})$ & 7.62 & 8.16 & a & 5.80 & 6.33 & a & 0 \\
\hline \multicolumn{8}{|c|}{ 7: $\mathrm{TAR}, \mathrm{c}=2 \times 10^{-3} \mathrm{~mol} \mathrm{~L}^{-1}+\mathrm{HAc}$} \\
\hline $\mathrm{As}(\mathrm{III})$ & 11.00 & 10.55 & 9.76 & 10.15 & 9.91 & $\mathrm{a}$ & 12.90 \\
\hline $\mathrm{As}(\mathrm{V})$ & 9.54 & 9.63 & 10.84 & 9.47 & 10.74 & a & 7.10 \\
\hline \multicolumn{8}{|c|}{$8: \mathrm{OX}, \mathrm{c}=2 \times 10^{-3} \mathrm{~mol} \mathrm{~L}^{-1}$} \\
\hline $\mathrm{As}(\mathrm{III})$ & 10.30 & 10.15 & 10.60 & 10.10 & 10.40 & $\mathrm{a}$ & 11.08 \\
\hline $\mathrm{As}(\mathrm{V})$ & 9.71 & 9.41 & 8.30 & 10.02 & 10.60 & $\mathrm{a}$ & 8.92 \\
\hline \multicolumn{8}{|c|}{ 9: $\mathrm{OX}, \mathrm{c}=2 \times 10^{-3} \mathrm{~mol} \mathrm{~L}^{-1}+\mathrm{HAc}$} \\
\hline $\mathrm{As}(\mathrm{III})$ & 10.06 & 9.60 & 6.75 & 6.87 & 7.40 & 6.05 & $\mathrm{a}$ \\
\hline $\mathrm{As}(\mathrm{V})$ & 11.73 & 11.07 & 16.25 & 16.16 & 13.04 & 13.95 & a \\
\hline \multicolumn{8}{|c|}{ 10: HAc } \\
\hline $\mathrm{As}(\mathrm{III})$ & 9.60 & 9.52 & 6.20 & $\mathrm{a}$ & 7.60 & $\mathrm{a}$ & 14.30 \\
\hline $\mathrm{As}(\mathrm{V})$ & 10.55 & 10.48 & 14.75 & $\mathrm{a}$ & 12.43 & a & 6.70 \\
\hline
\end{tabular}

Results expressed as mean values of duplicate $(n=2)$. ${ }^{a}$ Not measured.

\subsection{Preservation Studies of As(III/V) Stability in Natural Water Samples}

Arsenic occurs in groundwater predominately in its inorganic forms and the Eh and $\mathrm{pH}$ are the most important factors predicting inorganic As speciation. Under oxidizing conditions, increased concentrations of $\mathrm{As}(\mathrm{V})$ in groundwaters can be derived from the oxidation of sulfide minerals, particularly arsenopyrite. In reducing conditions at nearneutral $\mathrm{pH}, \mathrm{As}(\mathrm{III})$ is the dominant As species, derived from desorption of As bound to Fe and Mn mineral oxides [34]. The area of Osijek, in eastern Croatia, is located in the southern part of the Pannonian Basin. In the Pannonian Basin (Hungary, Romania, Croatia, and northern Serbia), groundwater resources have naturally high levels of arsenic, which makes it the largest region in Europe that is affected by high concentrations of this element in drinking water [35]. The comprehensive overview of the problems of natural arsenic pollution in eastern Croatia was given by Ujević et al. [36]. The authors analysed groundwater samples taken from 56 wells. Arsenic was detected in 46 of 56 samples and 
concentrations were between 1.3 and $491 \mu \mathrm{g} \mathrm{L}{ }^{-1}$. In approximately $64 \%$ of the sampled arsenic concentrations exceeded $10 \mu \mathrm{g} \mathrm{L}^{-1}$ and in 20 wells the concentrations were above $100 \mu \mathrm{g} \mathrm{L}{ }^{-1}$.

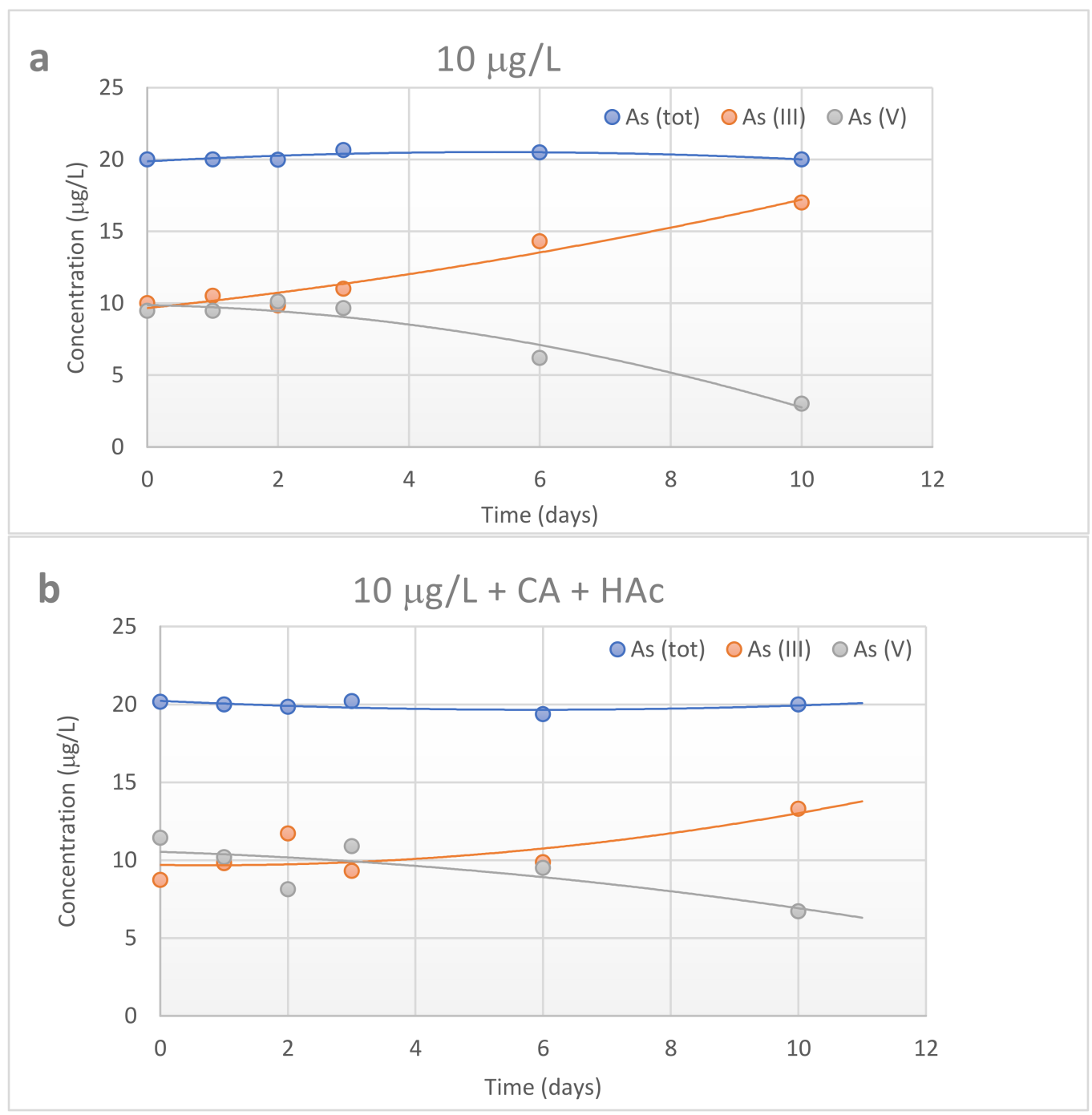

Figure 3. Graphs show the stability of the model solutions in (a) double-distilled water without preservatives and (b) with CA/HAc as a preservative. $\gamma(\mathrm{As}(\mathrm{III}))=\gamma(\mathrm{As}(\mathrm{V}))=10 \mu \mathrm{g} \mathrm{L}^{-1}$, $\gamma($ As (tot) $)=20 \mu \mathrm{g} \mathrm{L}^{-1}$.

Preservation studies in four natural samples collected from Croatia (Zagreb county and Osijek county) were conducted. The aim of the study was to examine the effect of the proposed preservatives and the combination of preservatives in natural samples with higher and lower contents of arsenic and iron. Different natural samples from different areas were used.

Samples were collected from wells and are presented in Table 2. As(tot) and As(III) content was determined on the first day, a few hours after collecting the samples and adding the preservatives. The verification of results, as well as the determination of iron was done by ICP-MS. pH values were determined in unpreserved samples. Preservations were made in the same way as for the model samples and from one original sample ten subsamples were made. All the preservatives were added in such way that their final concentration amounted to $2 \times 10^{-3} \mathrm{~mol} \mathrm{~L}^{-1}$, while the amount of acetic acid was $5 \%$. For all subsamples voltammograms were acquired until the complete oxidation of $\mathrm{As}$ (III) or reduction of $\mathrm{As}(\mathrm{V})$ occurs. The resulting graphs are presented in Figures 4-7. 
Table 2. Natural groundwater samples—-the sampling site, arsenic, iron content and $\mathrm{pH}$ value of the samples.

\begin{tabular}{|c|c|c|c|c|c|c|}
\hline Sample & Place of Origin & As (tot) $/ \mu \mathrm{g} \mathrm{L}^{-1}$ & As (III)/ $\mu \mathrm{g} \mathrm{L}^{-1}$ & As $(\mathrm{V}) / \mu \mathrm{g} \mathrm{L^{-1 }}$ & $\mathrm{Fe} / \mathrm{mg} \mathrm{L}^{-1}$ & $\mathrm{pH}$ \\
\hline A & Osijek & 110.0 & 48.5 & 61.5 & 130.0 & 8.42 \\
\hline B & Osijek & 164.8 & 118.0 & 46.8 & 88.3 & 8.02 \\
\hline $\mathrm{C}$ & Zagreb & 9.86 & 8.5 & 1.36 & 10.5 & 8.32 \\
\hline $\mathrm{D}$ & Zagreb & 16.62 & 8.46 & 8.16 & 10.15 & 8.24 \\
\hline
\end{tabular}

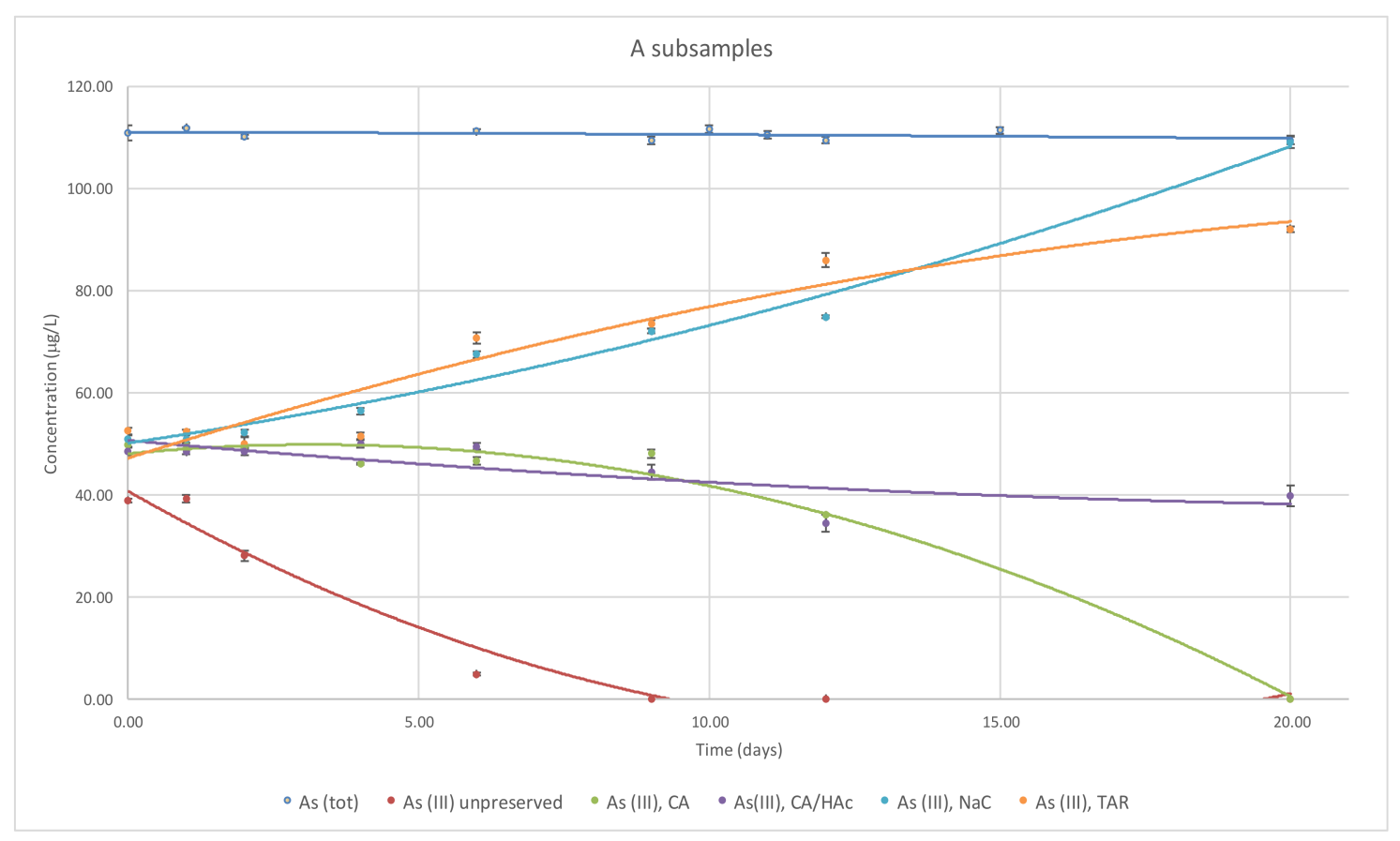

Figure 4. As(III) and As(tot) stability over time, dependent on the preservation treatment used—natural water sample A.

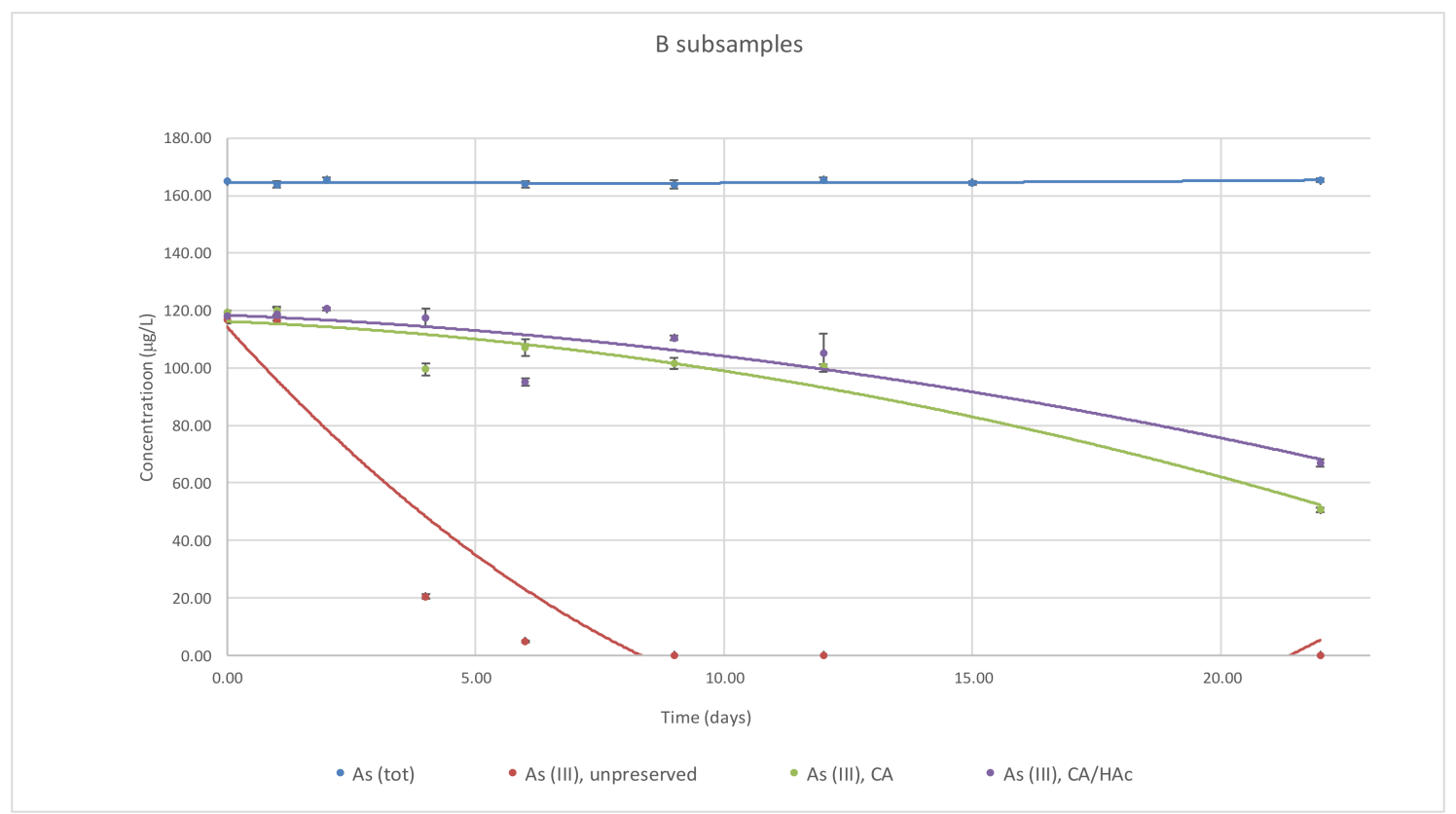

Figure 5. As(III) and As(tot) stability over time, dependent on the preservation treatment used-natural water sample B. 


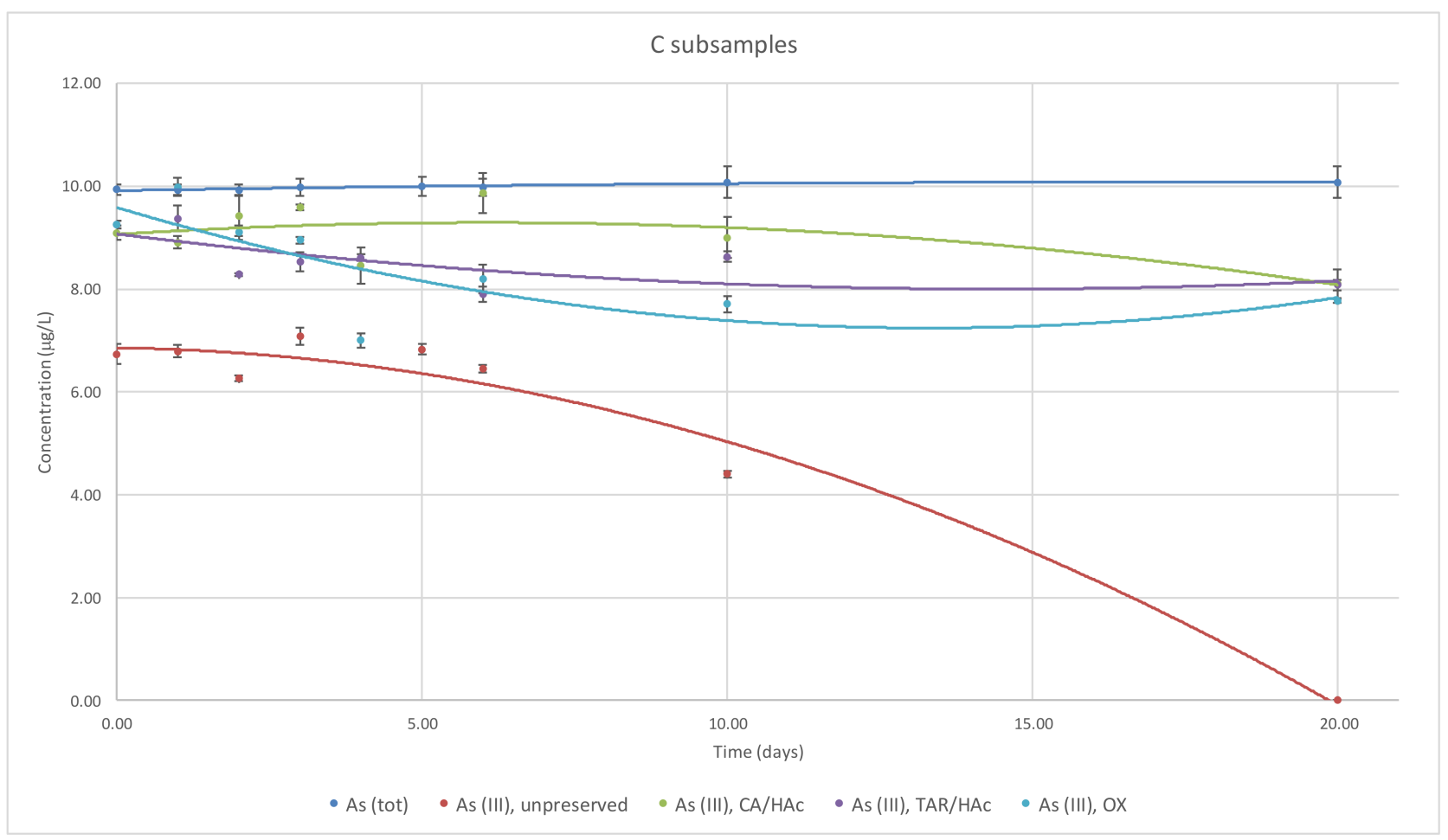

Figure 6. As(III) and As(tot) stability over time, dependent on the preservation treatment used-natural water sample C.

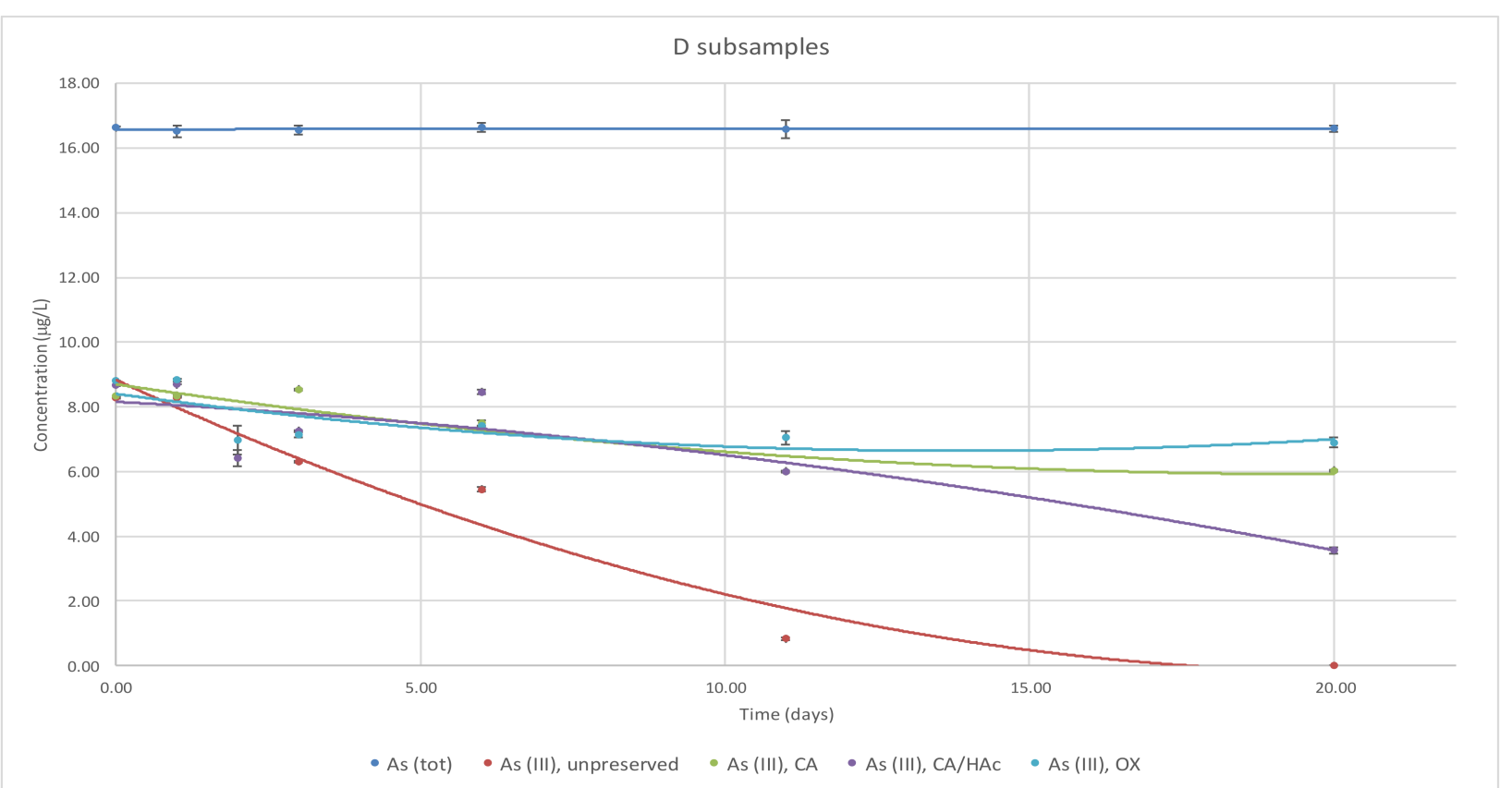

Figure 7. As(III) and As(tot) stability over time, dependent on the preservation treatment used—natural water sample D.

Figures 4 and 5 show the effect of different treatment methods on As(III/V) preservation in natural water samples from Osijek county. Sample A had a lower inorganic As(tot) concentration than the other sample (B) from the same area, but ahigher concentration of Fe (Table 2). Sample B had the highest concentration of As(tot) and As(III) of all tested samples. In these two samples, the As redox stability was improved by the addition of $\mathrm{CA}$ and acidification with HAc. These subsamples were stable for 8 days, while in untreated samples, the oxidation of As(III) was observed on the second day after sampling. 
Although a good preservation effect by acidification of natural samples was reported [21], the addition of HAc initially lowered the content of As(III) in sample B.

In samples collected in Zagreb county, which is not in the Pannonian Basin, lower As concentrations were determined. In all four samples, the As redox stability was substantially improved by preservation with $\mathrm{CA}$ and acidification with HAc, as well as with addition of tartrate and oxalate. In samples $C$ and $D$, little difference between the treated and untreated subsamples during the first five days was noticed, as can be seen in Figures 6 and 7.

To stabilize arsenic species in their original state, the redox activity of the coexisting Fe(III) and Fe(II) should be minimized. The formation of metal complexes can help to decrease the free metal-ion concentration, thereby inhibiting arsenic species' interconversion. The mobilization of arsenic in groundwater involves the desorption of arsenic from ferric oxide precipitates of aquifer sediments and/or oxidation of arsenopyrites (FeAsS), so As and Fe occur together in most groundwaters [37]. The oxidation of As(III), in conjunction with the photochemical reduction of Fe(III), takes place according to the following net reaction [37]:

$$
2 \mathrm{Fe}^{3+}+\mathrm{H}_{3} \mathrm{AsO}_{3}+\mathrm{H}_{2} \mathrm{O}+\mathrm{h} v \leftrightharpoons 2 \mathrm{Fe}^{2+}+\mathrm{H}_{3} \mathrm{AsO}_{4}+2 \mathrm{H}^{+}
$$

Hydroxyl radicals are produced when the $\mathrm{pH}>2$ and a water sample containing $\mathrm{Fe}(\mathrm{III})$ is exposed to light. These radicals react with As(III) to produce an intermediate $\mathrm{As}(\mathrm{IV})$ species, which then reacts with Fe(III) to produce Fe(II) and $\mathrm{As}(\mathrm{V})$. However, As(III) oxidation by $\mathrm{Fe}(\mathrm{III})$ is slowed with the presence of $\mathrm{Fe}(\mathrm{II})$ and Fe-complexing anions, and effectively stopped when light is excluded [38].

Finally, the total inorganic $\mathrm{As}(\mathrm{III}) / \mathrm{As}(\mathrm{V})$ concentrations were stable over the 7-day period for the CA-treated subsamples. Therefore, without treatment, the formation of the Fe coprecipitates caused a significant drop in the native As concentrations, while the CA treatment inhibited this process and preserved the native arsenic distribution in the four waters utilized in this study. The acidification of aqueous samples is a widely practiced protocol aimed at suppressing the precipitation of Fe by increasing its solubility. Acidification also helps in reducing microbial activity. Sample acidification is necessary to bring all Fe(III) to solution. Bender et al. used EDTA to preserve groundwater samples for 3 months without adding acetic acid [11]. However, other studies have shown that EDTA alone cannot preserve arsenic speciation, and $\mathrm{pH}$ adjustment to 3.2 is necessary to inhibit the oxidation of Fe(II) [39]. Acid preservation could be used for a wide range of surface water and groundwater samples containing dissolved Fe. However, though complexing agents are useful to preserve Fe-rich samples, the complexing agents-HAc combination is more effective in preserving arsenic speciation. The selection of a proper preservation strategy for arsenic species also depends on the analytical methodology to be followed.

Tables 3 and 4 show the summary results of As(III) concentrations on the first and sixth days of sampling, as well as the percent of devation from the initial As(III) concentration in natural water samples. It can be seen that combination of CA/HAc, as a preservative, can preserve the arsenic species for at least 6 days at room temperature in samples with lower arsenic and iron concentrations (not more than $10 \%$ deviation). This combination was successful for sample A, too, but not for sample B, which had the highest arsenic and iron concentrations. It is possible that the amount of added preservatives was not sufficient to complex this concentration of iron, but it is appropriate for lower concentrations. On the other hand, $\mathrm{NaC}$ was successful in preserving the distribution for about 6 days in samples $\mathrm{C}$ and $\mathrm{D}$, but not in samples $\mathrm{A}$ and $\mathrm{B}$. 
Table 3. Summary of the results for arsenic preservation using nine preservatives in natural groundwater samples A and B, in the presence of iron.

\begin{tabular}{|c|c|c|c|c|c|c|}
\hline \multirow[t]{2}{*}{ Sample } & \multicolumn{3}{|c|}{$\mathbf{A}$} & \multicolumn{3}{|c|}{ B } \\
\hline & $\begin{array}{l}\text { Initial As(III) } \\
\text { Concentration } \\
\quad\left(\mu \mathrm{g} \mathrm{L}^{-1}\right)\end{array}$ & $\begin{array}{c}\text { As(III) } \\
\text { Concentration } \\
\text { After } 6 \text { Days } \\
\left(\mu \mathrm{g} \mathrm{L}^{-1}\right)\end{array}$ & $\%$ Deviation & $\begin{array}{c}\text { Initial As(III) } \\
\text { Concentration } \\
\quad\left(\mu \mathrm{g} \mathrm{L}^{-1}\right)\end{array}$ & $\begin{array}{c}\text { As(III) } \\
\text { Concentration } \\
\text { After } 6 \text { Days } \\
\left(\mu \mathrm{g} \mathrm{L}^{-1}\right)\end{array}$ & \% Deviation \\
\hline Unpreserved & 38.68 & 5.10 & 86.81 & 115.88 & 4.55 & 96.07 \\
\hline $\mathrm{CA}$ & 50.00 & 46.20 & 7.60 & 118.73 & 100.90 & 15.02 \\
\hline $\mathrm{CA}+\mathrm{HAc}$ & 48.50 & 49.48 & 2.02 & 117.00 & 94.06 & 19.61 \\
\hline $\mathrm{NaC}$ & 51.50 & 68.00 & 32.04 & 107.90 & 64.11 & 40.58 \\
\hline $\mathrm{NaC}+\mathrm{HAc}$ & 76.00 & 64.36 & 15.32 & 140.18 & 68.89 & 50.86 \\
\hline TAR & 52.00 & 65.10 & 25.19 & 138.91 & 78.69 & 43.35 \\
\hline TAR + HAc & 49.20 & 66.04 & 34.23 & 143.80 & 99.86 & 30.56 \\
\hline OX & 62.12 & 19.02 & 69.38 & 106.15 & 32.80 & 69.10 \\
\hline $\mathrm{OX}+\mathrm{HAc}$ & 60.60 & 20.50 & 66.17 & 98.53 & 60.96 & 38.13 \\
\hline HAc & 60.00 & 36.11 & 39.82 & 18.13 & 77.45 & 327.19 \\
\hline
\end{tabular}

Table 4. Summary of the results for arsenic preservation, using nine preservatives in natural groundwater samples C and D, in the presence of iron.

\begin{tabular}{|c|c|c|c|c|c|c|}
\hline \multirow[t]{2}{*}{ Sample } & \multicolumn{3}{|c|}{$\mathrm{C}$} & \multicolumn{3}{|c|}{ D } \\
\hline & $\begin{array}{c}\text { Initial As(III) } \\
\text { Concentration } \\
\left(\mu \mathrm{g} \mathrm{L}^{-1}\right)\end{array}$ & $\begin{array}{c}\text { As(III) } \\
\text { Concentration } \\
\text { After } 6 \text { Days } \\
\left(\mu \mathrm{g} \mathrm{L}^{-1}\right)\end{array}$ & \% Deviation & $\begin{array}{c}\text { Initial As(III) } \\
\text { Concentration } \\
\quad\left(\mu \mathrm{g} \mathrm{L}^{-1}\right)\end{array}$ & $\begin{array}{c}\text { As(III) } \\
\text { Concentration } \\
\text { After } 6 \text { Days } \\
\left(\mu \mathrm{g} \mathrm{L}^{-1}\right)\end{array}$ & \% Deviaton \\
\hline Unpreserved & 6.87 & 4.50 & 34.39 & 8.30 & 5.50 & 33.73 \\
\hline CA & 9.00 & 4.80 & 46.67 & 8.35 & 7.43 & 11.02 \\
\hline $\mathrm{CA}+\mathrm{HAc}$ & 9.02 & 9.60 & 6.43 & 8.70 & 8.50 & 2.30 \\
\hline $\mathrm{NaC}$ & 8.50 & 5.15 & 39.41 & 8.65 & 6.20 & 28.32 \\
\hline $\mathrm{NaC}+\mathrm{HAc}$ & 9.30 & 9.86 & 6.02 & 6.40 & 6.00 & 6.25 \\
\hline TAR & 8.20 & 5.40 & 34.15 & 7.70 & 5.40 & 29.87 \\
\hline $\mathrm{TAR}+\mathrm{HAc}$ & 9.25 & 7.80 & 15.68 & 8.05 & 5.20 & 35.40 \\
\hline OX & 9.20 & 8.40 & 8.70 & 8.80 & 7.41 & 15.80 \\
\hline $\mathrm{OX}+\mathrm{HAc}$ & 9.21 & 1.97 & 78.61 & 8.15 & 5.02 & 38.40 \\
\hline HAc & 8.90 & 4.90 & 44.94 & 9.54 & 1.00 & 89.52 \\
\hline
\end{tabular}

\section{Conclusions}

It was shown that all tested complexing agents work as preservatives for As(III)/ As(V) concentration distribution for four days or more. Citric acid in combination with HAc is a suitable agent for stabilization during the storage of samples containing high concentrations (up to $100 \mathrm{mg} \mathrm{L}^{-1}$ ) of iron, and for the preservation of arsenic species for up to 7 days. Longer storage times are not advisable. Fe coprecipitates, formed in the aqueous phase, may adsorb arsenic, which results in a significant difference in the total arsenic concentration. Acidification with acetic acid can assist in avoiding their formation and in stabilising the inorganic arsenic species in their original state. It also clearly indicates that the initial distribution of $\mathrm{As}(\mathrm{III}) / \mathrm{As}(\mathrm{V})$ in untreated samples can undergo a larger change over the study period. This unpredictable change in distribution, coupled with the initial loss of arsenic to the formation of Fe-As coprecipitates, makes the use of no preservation agents an unsuitable experimental protocol and would result in questionable data. The proposed treatments were demonstrated to stabilize native As(III)/ As(V) concentrations in four well waters, held at room temperature for 7 days.

This data indicates the potential of utilizing citric acid and sodium citrate in combination with HAc as a means of preserving As(III) and As(V) in drinking waters with high iron levels. Further research is needed, in terms of testing different concentrations of 
added agents and without the presence of light. The applied electrochemical method for the determination of arsenic with an scTRACE Gold electrode proved to be very useful and practical in this type of testing.

Author Contributions: Conceptualization, A.A. and A.K.; methodology, A.A.; investigation, A.A. and A.K.; resources, N.G.; writing-original draft preparation, A.A. and N.G.; writing-review and editing, A.K. and N.G.; visualization, A.A.; supervision, A.K. and N.G.; funding acquisition, A.K. All authors have read and agreed to the published version of the manuscript.

Funding: This research was funded by the European Regional Development Fund grant number KK.01.1.1.02.0004 "Food Safety and Quality Centre” project.

Institutional Review Board Statement: Not applicable.

Informed Consent Statement: Not applicable.

Data Availability Statement: The data presented in this study are available on request from corresponding author.

Acknowledgments: The authors thank the Teaching Institute of Public Health "Andrija Štampar" in Zagreb, where all experimental work was done.

Conflicts of Interest: The authors declare no conflict of interest.

\section{References}

1. Ardini, F.; Dan, G.; Grotti, M. Arsenic speciation analysis of environmental samples. J. Anal. At. Spectrom. 2020, 35, 215-237. [CrossRef]

2. Sodhi, K.K.; Kumar, M.; Agrawal, P.K.; Singh, D.K. Perspectives on arsenic toxicity, carcinogenicity and its systemic remediation strategies. Environ. Technol. Innov. 2019, 16, 100462. [CrossRef]

3. Yu, X.; Cui, W.; Wang, Q.; Guo, Y.; Deng, T. Speciation analysis of arsenic in samples containing high concentrations of chloride by LC-HG-AFS. Anal. Bioanal. Chem. 2019, 411, 7251-7260.

4. Lukojko, E.; Talik, E.; Gagor, A.; Sitko, R. Highly selective determination of ultratrace inorganic arsenic species using novel functionalized miniaturized membranes. Anal. Chim. Acta 2018, 1008, 57-65. [CrossRef]

5. Cassone, G.; Chillé, D.; Foti, C.; Giuffré, O.; Ponterio, R.C.; Sponer, J.; Saija, F. Stability of hydrolytic arsenic species in aqueous solutions: $\mathrm{As}^{3+}$ vs. As ${ }^{5+}$. Phys. Chem. Chem. Phys. 2018, 20, 23272-23280. [CrossRef]

6. World Health Organization. Arsenic-World Health Organization. Fact Sheets. 2018. Available online: https://www.who.int/ news-room/fact-sheets/detail/arsenic (accessed on 3 March 2019).

7. Hung, D.Q.; Nekrassova, O.; Compton, R.G. Analytical methods for inorganic arsenic in water: A review. Talanta 2004, 64, 269-277. [CrossRef] [PubMed]

8. Hall, G.E.M.; Pelchat, J.C.; Gauthier, G.J. Stability of inorganic arsenic (III) and arsenic (V) in water samples. J. Anal. At. Spectrom. 1999, 14, 205-213. [CrossRef]

9. Tallman, D.E.; Shaikh, A.U. Redox stability of inorganic arsenic (III) and arsenic (V) in aqueous solution. Anal. Chem. 1980, 52, 196-199. [CrossRef]

10. Rassler, M.; Michalke, B.; Schramel, P.; Schuste-Hostede, S.; Kettrup, A. Speciation of inorganic arsenic and selenium in contaminated ground water samples-distribution and long-term stability of species. Int. J. Environ. Anal. Chem. 1998, 72, 195-203. [CrossRef]

11. Bednar, A.J.; Garbarino, J.R.; Ranville, J.F.; Wildeman, T.R. Preserving the distribution of inorganic arsenic species in groundwater and acid mine drainage samples. Environ. Sci. Technol. 2002, 36, 2213-2218. [CrossRef] [PubMed]

12. Oliveira, V.; Sarmiento, A.M.; Gomez-Ariza, J.L.; Nieto, J.M.; Sanchez-Rodas, D. New preservation method for inorganic arsenic speciation in acid mine drainage samples. Talanta 2006, 69, 1182-1189. [CrossRef] [PubMed]

13. Pillay, L.; Kindness, A. A preliminary investigation into the stability of inorganic arsenic species in laboratory solutions simulating sediment pore water. S. Afr. J. Chem. 2016, 69, 9-14. [CrossRef]

14. Williams, M. Arsenic in mine waters: An international study. Environ. Geol. 2001, 49, 267-278. [CrossRef]

15. Welch, A.H.; Westjohn, D.B.; Helsel, D.R.; Wanty, R.B. Arsenic in ground water of the United States: Occurrence and geochemistry. Ground Water 2000, 38, 589-604. [CrossRef]

16. Daus, B.; Weiss, H.; Mattusch, J.; Wennrich, R. Preservation of arsenic species in water samples using phosphoric acid—Limitations and long-term stability. Talanta 2006, 69, 430-434. [CrossRef] [PubMed]

17. Apelblat, A. Citric Acid; Springer International Publishing: Cham, Switzerland, 2014; Volume 1.

18. Saritha, A.; Raju, B.; Ramachary, M.; Raghavaiah, P.; Hussain, K.A. Synthesis, crystal structure and characterization of chiral, three-dimensional anhydrous potassium tris(oxalato)ferrate (III). Physica B Condens. Matter 2012, 407, 4208-4213. [CrossRef]

19. Kassaian, J.M. Ullmann's Encyclopedia of Industrial Chemistry; Wiley-VCH: Weinheim, Germany, 2002; Volume 35, p. 671. 
20. Smedley, P.L.; Kinniburgh, D.G. A review of the source, behaviour and distribution of arsenic in natural waters. Appl. Geochem. 2002, 17, 517-568. [CrossRef]

21. McCleskey, R.B.; Nordstrom, D.K.; Maest, A.S. Preservation of water samples for arsenic(III/V) determinations: An evaluation of the literature and new analytical results. Appl. Geochem. 2004, 19, 995-1009. [CrossRef]

22. Döker, S.; Yılmaz, M. Speciation of arsenic in spring, well, and tap water by high-performance liquid chromatography-inductively coupled plasma-mass spectrometry. Anal. Lett. 2018, 51, 254-264. [CrossRef]

23. Lee, H.G.; Kwon, J.Y.; Chung, D.S. Sensitive arsenic speciation by capillary electrophoresis using UV absorbance detection with on-line sample preconcentration techniques. Talanta 2018, 181, 366-372.

24. Dominiquez-Alvarez, J. Capillary electrophoresis coupled to electrospray mass spectrometry for the determination of organic and inorganic arsenic compounds in water samples. Talanta 2020, 212, 120803. [CrossRef] [PubMed]

25. Yang, M.; Liamtsau, V.; Fan, C.; Sylvers, K.L.; McGoron, A.J.; Liu, G.; Fu, F.; Cai, Y. Arsenic speciation on silver nanofilms by surface-enhanced Raman spectroscopy. Anal. Chem. 2019, 91, 8280-8288. [CrossRef] [PubMed]

26. Wei, C.; Liu, J. A new hydride generation system applied in determination of arsenic species with ion chromatography-hydride generation-atomic fluorescence spectrometry (IC-HG-AFS). Talanta 2007, 73, 540-545. [CrossRef]

27. Dai, X.; Nekrassova, O.; Hyde, M.E.; Compton, R.G. Anodic stripping voltammetry of arsenic (III) using gold nanoparticlemodified electrodes. Anal. Chem. 2004, 76, 5924-5929. [CrossRef] [PubMed]

28. Jagner, D.; Årén, K. Derivative potentiometric stripping analysis with a thin film of mercury on a glassy carbon electrode. Anal. Chim. Acta 1978, 100, 375-388. [CrossRef]

29. Ostapczuk, P.; Valenta, P.; Rützel, H.; Nürnberg, H.W. Application of differential pulse anodic stripping voltammetry to the determination of heavy metals in environmental samples. Sci. Total. Environ. 1987, 60, 1-16. [CrossRef]

30. Chadima, P.; Švancara, I.; Pihlarb, B.; Vytřasa, K. Gold-Plated Carbon Paste Electrodes for Anodic Stripping Determination of Arsenic. Collect. Czech. Chem. Commun. 2000, 65, 1035-1046. [CrossRef]

31. Salaün, P.; Planer-Friedrich, B.; van den Berg, C.M.G. Inorganic arsenic speciation in water and seawater by anodic stripping voltammetry with a gold microelectrode. Anal. Chim. Acta 2007, 585, 312-322. [CrossRef]

32. Bednar, A.J.; Garbarino, J.R.; Burkhardt, M.R.; Ranville, J.F.; Wildeman, T.R. Field and laboratory arsenic speciation methods and their application to natural-water analysis. Water Res. 2004, 38, 355-364. [CrossRef]

33. Cherry, J.A.; Shaikh, A.U.; Tallman, D.E.; Nicholson, R.V. Arsenic species as an indicator of redox conditions in groundwater. Dev. Water Sci. 1979, 12, 373-392.

34. Anawar, H.M.; Akai, J.; Komaki, K.; Terao, H.; Yoshioka, T.; Ishizuka, T.; Safiullah, S.; Kato, K. Geochemical occurrence of arsenic in groundwater of Bangladesh: Sources and mobilization processes. J. Geochem. Explor. 2003, 77, 109-131. [CrossRef]

35. Romić, Ž.; Habuda-Stanić, M.; Kalajdžić, B.; Kuleš, M. Arsenic distribution, concentration and speciation in groundwater of the Osijek area, eastern Croatia. Appl. Geochem. 2011, 26, 37-44. [CrossRef]

36. Ujević, M.; Duić, Ž.; Casiot, C.; Sipos, L.; Santo, V.; Dadić, Ž.; Halamić, J. Occurrence and geochemistry of arsenic in the groundwater of Eastern Croatia. Appl. Geochem. 2010, 25, 1017-1029. [CrossRef]

37. Herath, I.; Vithanage, M.; Bundschuh, J.; Maity, J.P.; Bhattacharya, P. Natural arsenic in global groundwaters: Distribution and geochemical triggers for mobilization. Curr. Pollut. Rep. 2016, 2, 68-89. [CrossRef]

38. Emmett, M.T.; Khoe, G.H. Photochemical oxidation of arsenic by oxygen and iron in acidic solutions. Water Res. 2001, 35, 649-656. [CrossRef]

39. Samanta, G.; Clifford, D.A. Preservation of inorganic arsenic species in groundwater. Environ. Sci. Technol. 2005, 39, 8877-8882. [CrossRef] 